\title{
Comparative Analysis of Nutritional Composition of Fresh and Dried Atama (Heinsia crinita) Leaves obtained from Port Harcourt Fruit Market
}

\author{
Tamunodiepriye Ezekiel* and Leera Solomon \\ Department of Science Laboratory Technology, School of Science and Technology, Captain Elechi Amadi Polytechnic, Port Harcourt, Nigeria
}

*Corresponding author: Tamunodiepriye Ezekiel, Department of Science Laboratory Technology, School of Science and Technology, Captain Elechi Amadi Polytechnic, Port Harcourt, Nigeria

\begin{abstract}
The study was aimed at determining the nutritional composition of fresh and dried atama (Heinsia crinita) leaves. Atama leaves were purchased from fruit market in D-Line, Port Harcourt, Nigeria and analyzed in the laboratory for their nutritional compositions. Proximate analysis of Fresh Atama Leaf (FAL) indicated 60.32 ppm of moisture, 5.31 ppm (ash), 7.21 ppm (protein) and 3.65 ppm (fat) contents while fibre had $8.08 \mathrm{ppm}$, carbohydrate $(24.19 \mathrm{ppm})$ and vitamin $(8.21 \mathrm{ppm})$. However, Dried Atama Leaf (DAL) recorded $58.52 \mathrm{ppm}$ for moisture, $4.14 \mathrm{ppm}$ (ash), $5.57 \mathrm{ppm}$ (protein), $2.34 \mathrm{ppm}$ (fat) and $7.12 \mathrm{ppm}$ for fibre while values of 22.86 ppm and $7.83 \mathrm{ppm}$ were obtained for carbohydrate and vitamin respectively. The mineral contents in FAL indicated presence of Ca, $\mathrm{Fe}, \mathrm{Mg}$ and $\mathrm{Zn}$ as $40.04 \mathrm{ppm}, 4.54 \mathrm{ppm}, 5.96 \mathrm{ppm}$ and $2.79 \mathrm{ppm}$ while $\mathrm{Na}$ and $\mathrm{K}$ were $6.23 \mathrm{ppm}$ and $4.43 \mathrm{ppm}$. DAL had Ca, Fe, Mg and $\mathrm{Zn}$ as $18.73 \mathrm{ppm}, 2.90 \mathrm{ppm}, 4.75 \mathrm{ppm}$ and $1.53 \mathrm{ppm}$ while $\mathrm{Na}$ and K recorded values of $4.08 \mathrm{ppm}$ and 3.51 ppm respectively. Both fresh and dried atama leaves are of nutritional benefits to the body, although the fresh leave was significantly $(\mathrm{p}<0.05)$ higher in nutrients than the dried. Consumption of the analyzed leaves is advised as they supply adequate energy and minerals for metabolic processes needed in maintenance of life.
\end{abstract}

Keywords: Heinsia crinite; Vegetable; Healthy Citizenry; Proximate Analysis; Energy; Protein

\section{Introduction}

Green leafy vegetables play a vital role in the food culture of Nigerians and Africans as a whole [1]. A great variety of nutrients are found in vegetables consumed everyday through leaves, spinach, cabbage, carrot, onions, tomatoes and many others [2]. In fact, vegetables are the cheapest and most available sources of important nutrients and they contributed substantially to protein, mineral salts, vitamins, fibres, essential amino acids and other essential nutrients which are usually inadequately supplied in daily diets [3]. In addition, green leafy vegetables are used in the diet of postpartum woman during which time it is claimed that they aid the contraction of the uterus [4]. These vegetables are important commodities for poor households mostly because their prices are relatively affordable compared with other food items [1]. Scarcity of vegetable in the diet is a major cause of vitamin A deficiency, which causes blindness and even death in young children throughout the Arid and semi-Arid areas of Africa [5]. The medicinal value of some of these plants lies in some chemical substances that produce a definite physiological action on the body [6]. The most important features of some fresh vegetables are that they contain the nutritional value of economic importance and they are source of food [2,7]. Vegetable is a source of many nutrients including potassium fiber, folate and vitamins $\mathrm{A}, \mathrm{E}$ and $\mathrm{C}$ respectively.

Eating a diet rich in vegetables may reduce risk of stroke, cancer, heart disease and type- 2 diabetes [7]. More so, eating vegetable can make weight management easier [8]. According to the centre for disease control and prevention, most produce are low in calories compared to other foods, so filling up on vegetables can aid in weight loss $[8,9]$. Heinsia crinite is a common vegetable in the south-eastern part of Nigeria which belongs to the family of "Rubiaceae". It is locally known as "Atama" leave [8]. Atama leave is a shrub with woody stem and branches; it is indigenous to West Africa, especially the southern part of Nigeria. The leave extract is 
used in the treatment of skin rashes and the leaves for umbilical hernia. The Leave juice is also use in the treatment of various other related gastrointestinal disorders [9]. Atama leaf has also been used as a component of various herbal portions in ethno-medicine and traditional drugs formulations [6]. The plant parts have also been previously used in the treatment of umbilical hernia and skin rashes $[9,10]$. Atama Soup is a delicious palm nut soup, native to the Efiks/Ibibio people of southern Nigeria.

This traditional Nigerian soup is very similar to popular Banga soup; the major difference is in the Atama leaves which give the Atama soup its distinctive taste andaroma. Atama leaves is an aromatic vegetable, wildly grown in the southern parts of Nigeria but can also be found in the eastern boundaries [1]. In the absence of atama leaves, Nigerians in diaspora can "remix" the taste with a combination of bitter leaf and a little Tarragon. The study was aimed at comparatively analyzing the Nutritional composition of fresh and dried Atama (Heinsia crinita) leave obtained from Fruit Market in D-Line, Port Harcourt, Nigeria.

\section{Materials and Methods}

\section{Sample collection and analysis}

Fresh and dried samples of Atama (Heinisia crinita) leaves were purchased from Rumuokwuta Market in Port Harcourt, Rivers State and transported to the laboratory for processing and analysis. The leaves were washed separately using clean tap water and oven dried at $65^{\circ} \mathrm{C}$ for $4 \mathrm{hr}$. Thereafter, it was milled into powder before being analysed following the methods of Ezekiel et al. [11]. Processed leaf samples were examined separately for their nutritional contents using the method recommended by the Association of Analytical Chemists [12,13]. Buck scientific Atomic Absorption Spectrophotometer (AAS) (Shimadzu model AA-7000) methods was used in the determination of the essential mineral components of the fresh and dried leaves.

\section{Statistical analysis}

The data obtained in the study were subjected to statistical analysis to determine level of significance using the two-way analysis of variance (ANOVA). A value of $\mathrm{P}<0.05$ was accepted as significant while value of $\mathrm{P}>0.05$ was considered as not significant.

\section{Results and Discussion}

The nutritional benefits of green vegetables are increasingly tremendous in the world today due to their unrestrained roles in human health and constituent active ingredients. Atama (Heinsia crinite), a common vegetable in the south-eastern part of Nigeria has been used as a component of various cuisines and was analyzed for their nutritional contents. The results obtained for both proximate and minerals composition of fresh Atama leaf (FAL) and dried Atama Leaf (DAL) are presented in Figs. 4.1 to 4.2 respectively. Fig. 4.1 shows the of proximate composition of FAL to contained 60.32 ppm of moisture, $5.31 \mathrm{ppm}$ of ash, $7.21 \mathrm{ppm}$ of protein and 3.65 ppm of fat respectively. Others are fibre (8.08 ppm), carbohydrate (24.19 ppm) and vitamin (8.21 ppm). Dried Atama leaf (DAL) had proximate compositions that ranged from $58.52 \mathrm{ppm}$ for moisture, $4.14 \mathrm{ppm}$ (ash), $5.57 \mathrm{ppm}$ (protein), $2.34 \mathrm{ppm}$ for fat and $7.12 \mathrm{ppm}$ for fibre content respectively. Results indicated values of 22.86 ppm, and 7.83 ppm was obtained for carbohydrate and vitamin respectively (Figure 1). The mineral contents of the FAL as well as the DAL are presented in Figure 2. The results obtained indicated that calcium (Ca), Iron ( Fe), Magnesium ( $\mathrm{Mg}$ ) and Zinc ( $\mathrm{Zn}$ ) had mineral composition of $40.04 \mathrm{ppm}, 4.54 \mathrm{ppm}, 5.96 \mathrm{ppm}$ and 2.79 ppm respectively while sodium $(\mathrm{Na})$ and potassium $(\mathrm{K})$ recorded values of $6.23 \mathrm{ppm}$ and $4.43 \mathrm{ppm}$ respectively. The dried sample of DAL had calcium (Ca), Iron (Fe), Magnesium (Mg) and Zinc (Zn) composition of $18.73 \mathrm{ppm}, 2.90 \mathrm{ppm}, 4.75 \mathrm{ppm}$ and $1.53 \mathrm{ppm}$ respectively. Other minerals such as sodium $(\mathrm{Na})$ and potassium (K) recorded values of $4.08 \mathrm{ppm}$ and $3.51 \mathrm{ppm}$ respectively.

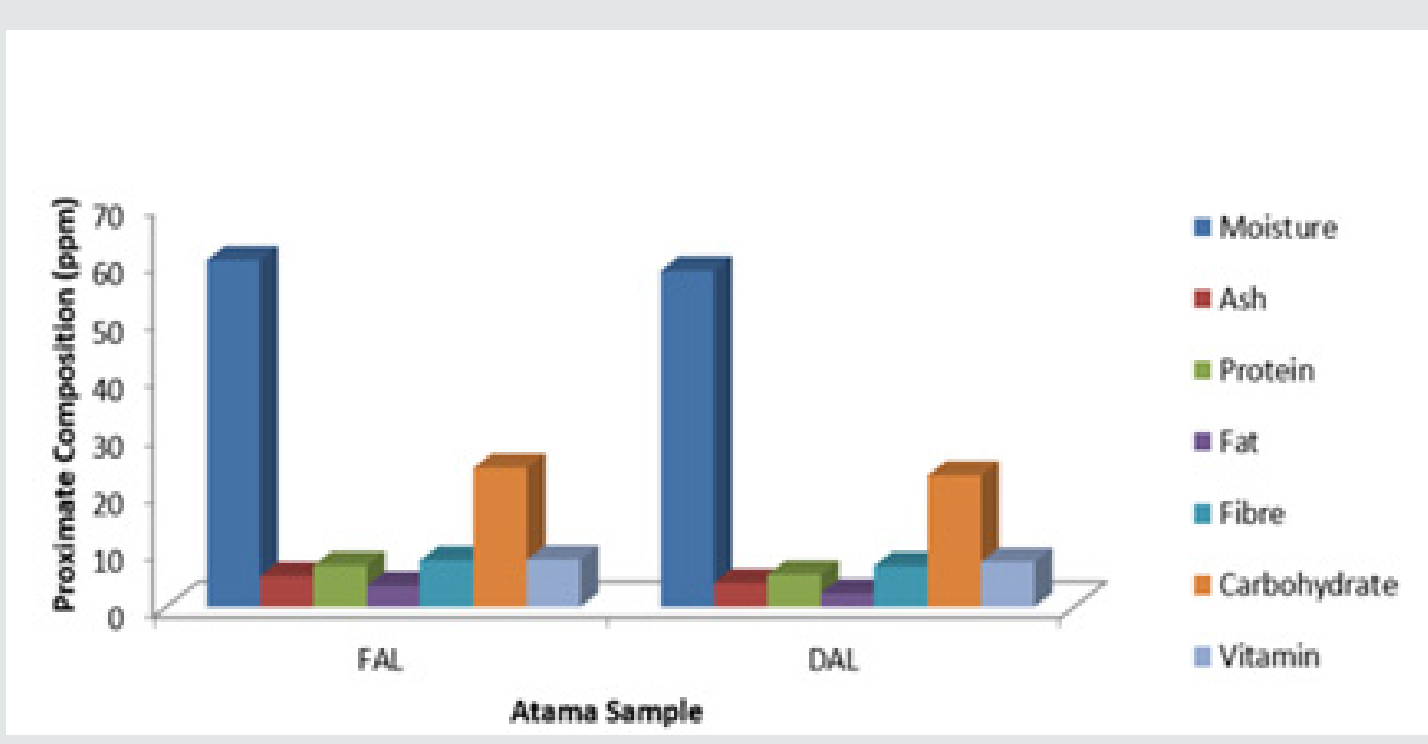

Figure 1: Proximate Composition of Fresh and Dried Atama. 


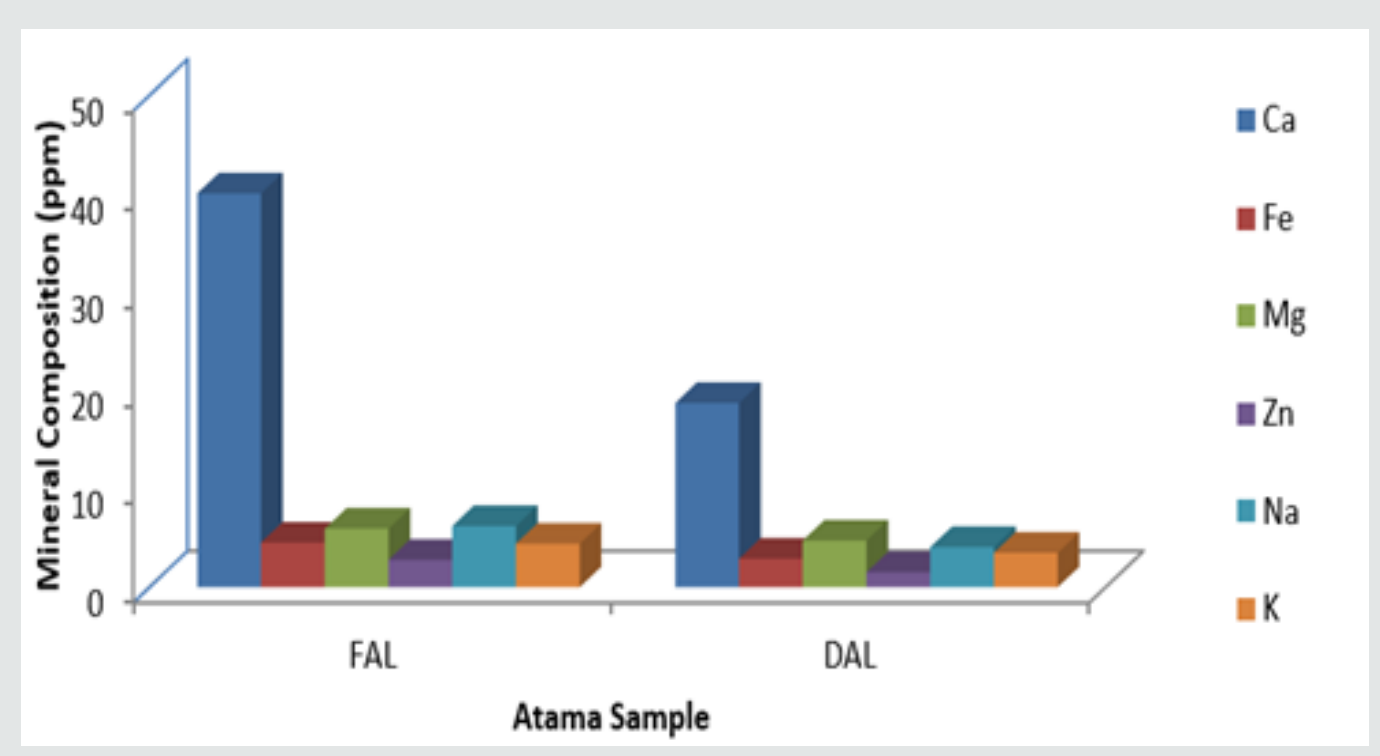

Figure 2: Mineral Composition of Fresh and Dried Atama.

Magnesium (Mg) is important in decreasing blood pressure by dilating arteries and preventing abnormal heart rhythm [10]. It is important in cell proliferation, contributing to Deoxyribonucleic Acid (DNA) and Ribonucleic Acid (RNA) synthesis by acting as a catalyst to enzymes involved in metabolic function. Magnesium ions also function to protects soft tissues from hardening and also protects the linings of the arteries from stress due to fluctuations in blood pressure $[11,12]$. Magnesium and vitamin B6 when combined help dissolve calcium phosphate kidney stones. The deficiency of magnesium $(\mathrm{Mg})$ in the body could result to the interference with the transmission of muscle and nerve impulses and can result in irritability, muscle weakness, dizziness and heightened symptoms of PMS (Premenstrual Syndrome). All these are found in the tested of leafy vegetable, but more in scent leaf which recorded the highest concentration of Magnesium mineral therein [13-16]. Nutrients are very important in human system for diverse metabolic activities. Fig. 4.1 shows the proximate composition of FAL to contained 60.32 ppm of moisture, $5.31 \mathrm{ppm}$ of ash, $7.21 \mathrm{ppm}$ of protein and 3.65 ppm of fat respectively. Others are fibre (8.08 ppm), carbohydrate (24.19 ppm) and vitamin (8.21 ppm). Dried sample of Atama leaf (DAL) had proximate composition that ranged from $58.52 \mathrm{ppm}$ for moisture, $4.14 \mathrm{ppm}$ for ash and $5.57 \mathrm{ppm}$ for protein. Others include $2.34 \mathrm{ppm}$ for fat and $7.12 \mathrm{ppm}$ for fibre content while values of $22.86 \mathrm{ppm}$, and $7.83 \mathrm{ppm}$ were obtained for carbohydrate and vitamin respectively (Figure 1). The result showed a high fraction of moisture content in fresh leave of atama than the dried leaves and the percentage total ash, crude protein, fat, crude fiber and carbohydrate was higher in fresh leave of atama than the dried leaves. High moisture content of vegetables helps in maintaining the protoplasmic contents of the cells [10]. It also supports a greater activity of water-soluble enzymes and co-enzymes needed for metabolic activities of these leafy vegetables [14]. However, high moisture content makes vegetables susceptible to spoilage [10]; microorganisms that cause spoilage are known to thrive in foods containing high moisture content [14]. According to Gbadamosi et al. [14], ash content in leafy vegetables is a reflection of the amount of mineral elements present in the vegetable. Also, high ash content in a leafy vegetable would imply high mineral content, hence very nutritious But Ukam, [15] reported that it could be the reveres if it contained toxic metals which also contribute to the ash percentage in leafy vegetables. Therefore, high ash content is not necessarily a conclusive factor regarding the health benefits of vegetables. Protein has been reported to be an important part of diets that is used in body building and repair of tissues [16]. Crude fibres or roughages are non-hydrolysable polysaccharides which can be in soluble or insoluble state and increase faecal bulk. They form complexes with protein, sugars and cholesterol. When taken in excess, they help to reduce the risk of colon cancer and scrub out the intestines leaving a much healthier digestive system. Dietary fibre functions help in maintaining bowel movement and can prevent diverticulosis by aiding the absorption of trace elements in the guts. Ash content in leafy vegetables is directly proportional to the mineral elements present in the vegetables. This implies the higher the ash content, the more nutritional the plant would be. The human system needs constant supply of Adenosine Triphosphate (ATP) to function properly by striking a balance between external and internal factors. This energy inform of ATP could be gotten from carbohydrate. The deficiency of carbohydrate in our diet has resulted in poor mental function, fatigue, endurance and lack of stamina. The fats and oil from vegetables have been shown to possess hypolipidemic activity and therefore could ameliorate the occurrence of diseases associated with hyperlipidemia like coronary artery disease, myocardial infarction, cerebrovascular accident and hypertension.

This decrease in blood lipid exhibited by these vegetables may have been their role in down regulation of Nicoatinamide Adenine Dinucleotide Phosphate (NADPH) and reduced equivalent of Nicoatinamide Adenine Dinucleotide (NADH) cofactors involved in the metabolism of fatty acids [14]. Dietary fat is a major determinant 
of palatability of food [17]. It has also been reported that vegetables fats and oil lower blood lipids, hence contribute to reduction in the occurrence of diseases associated with damage of coronary artery [18]. Fiber is known to cleanse the digestive tract, remove potential carcinogens from the body, as well as keep blood sugar levels under control [15]. Carbohydrate provides the body with fuel and energy that is required for daily activities and exercise. The human body needs constant supply of energy to function properly, and lack of carbohydrate in the diet may result in tiredness or fatigue, poor mental function and lack of endurance and stamina. The results obtained indicated that calcium (Ca), Iron (Fe), Magnesium ( $\mathrm{Mg}$ ) and Zinc (Zn) had mineral composition of 40.04 ppm, 4.54 ppm, 5.96 ppm and 2.79 ppm respectively while sodium ( $\mathrm{Na}$ ) and potassium (K) recorded values various concentrations of $6.23 \mathrm{ppm}$ and 4.43 ppm. The DAL had calcium (Ca), Iron (Fe), Magnesium (Mg) and Zinc (Zn) had mineral composition of 18.73 ppm, 2.90 ppm, 4.75 ppm and 1.53 ppm respectively while sodium (Na) and potassium (K) recorded values of $4.08 \mathrm{ppm}$ and $3.51 \mathrm{ppm}$ respectively (Figure 2). Copper contributes in hemoglobin formation, red blood cells in iron and energy metabolism. It also helps in elastin formation, a vital skin protein that helps keep skin healthy and flexible, also helps in collagen formation, another vital protein for building bones, muscles, and connective tissues. It is needed to maintain healthy nerves and joints.

It necessary to state here that excessive copper intake can lead to toxicity. Toxic levels of copper can cause vomiting, joints and muscle pain and with extreme overdosing it can even be fatal. Iron is an important trace element in the human body, it plays roles information of hemoglobin, control of infection and cell mediated immunity. Its deficiency causes anemia. Iron toxicity is very serious and can lead to increased free radical production which can ultimately lead to heart disease and cancer. Proteins are the building blocks of life and every cell in the human body contains protein which helps to repair and replace worn out tissues. Some proteins have catalytic activity and function as enzymes while others serve as structural elements, signal receptors, or transporters that carry specific substances in or out of the cells $[19,20]$. The deficiency of protein in diet especially in children leads to kwashiorkor and marasmus symptoms like retarded growth, fatty liver, oedema of the belly and legs. These disparities in the protein contents by these researchers may be attributed to the differences and types of manure applied to enrich the nitrogen content of the soil where these vegetables are harvested. Zinc is required for collagen formation and the synthesis of protein.

It is an essential micronutrient for human growth and immune functions and also functions as part of enzymes and as cofactor. It aids the immune system and prevents formation of free radicals. It protects the liver and is required for bone development. It maintains the proper balance and absorption of several vitamins in the body. Zinc deficiency results in a decreased sense of smell and taste, thin brittle nails, hair loss, high cholesterol, increased susceptibility to illness and infection, recurring colds and slow healing. The elicitations of these properties by vegetables are held greatly to the biological active substances possessed by them such as secondary metabolites, high vitamin and mineral contents. They equally help in the amelioration and prevention of diseases. Researchers have established the fact that vegetables play a vital role in the contribution of essential nutrients to the body which help to maintain a healthy lifestyle and the prevention of diseases [2123]. On that note, the proximate compositions: moisture content, total ash, crude fat, crude protein, fibre content and carbohydrate were determined in Atama.

\section{Conclusion and Recommendations}

Results revealed the presence of copper, iron, magnesium and zinc in the fresh and dried leafy vegetables of Atama. The nutritional benefits of this plant leaves are increasingly tremendous in the world today due to their unrestrained roles in human health and constituent active ingredients in the leave. Vegetables are fresh edible portions of herbaceous plants which can be eaten raw or cooked and act as important sources of protective foods. It may interest you to know that this and many other plants produce food in their leaves, but do not store foods in leaves. The significance of leafy vegetables have immensely been manifested in human diet supplying the body with low calories, substantial amount of carbohydrates, oil, minerals, vitamins and act as precursors of hormones as well as protein and energy. The significance and wakefulness of nutrition in public health problems and challenges have widened the horizon of the roles of nutrients in food. The results obtained showed that the two leaves are of important benefits to the body. It was observed that the fresh leaves are higher in nutritional composition than the dried leaf. Hence, further analysis like the mineral component as well as the level of pollutants and anti-nutrients present in these vegetables may be carried out in order to accurately determine the nutritional value. Atama have adequate nutritional value but its composition vary slightly in both fresh and dried leaves. Consumption of the analyzed atama is advised as they supply energy, protein and minerals for metabolic processes needed in the maintenance of a healthy citizenry.

\section{References}

1. Mensah JK, Okoli RI, Ohaju Obodo JO, Eifediyi K (2008) Phytochemical, Nutritional and medicinal properties of some leafy vegetables consumed by Edo people of Nigeria. African Journal of Biotechnology 7(14): 2304-2309.

2. Okafor D, Okoro SM (2004) The useful plants of West Tropical Africa. Families MR, Royal botanic Garden J 4: 805.

3. Gaga TC, Gaga HE (1999) Nutritive value and of blanching on trypsin and chymotrypsin inhibitor activities of selected leafy vegetables. Plant Foods Human Nutrition 54(3): 271-283.

4. Emebu PU, Anyika U (2004) Proximate and composition of Kale (Brassica oleracea) grown in Delta State, Nigeria. Pak Journal Nutrition 10: 190-194.

5. Okigbo BN (1986) Broadening the Food base in Africa. The potential of traditional food plants. Food Nutritional 12: 4-17.

6. Edeoga HO, Okwu DE, Mbaebie BO (2005) Phytochemical substituents of some Nigerian medicinal plants. African Journal of Biotechnology 4 (7): 685-688.

7. Itah AY (1997) Bactericidal and bacteriostatic effect of edible leafy vegetable extract on growth of canned food borne bacteria. Trans Nig Society Bio Conserv 6: 103-111. 
8. Okokon JE, Anita BS, Umoh EE (2009) Antiulcerogenic activity of ethanolic leaf extract of Lasianthera Africana. African Journal of Traditional complement 6: 150-154.

9. Etukudo I (2003) Ethnobatany: Conventional and Traditional Use of plants; Verdict Press: Uyo, Nigeria.

10. Fagbohun ED, Lawal OU, Ore ME (2012) The Proximate, mineral and photochemical analysis of the leaves of Ocimum grattssimum L., Melanthera Scandens A. and Leea guineesis L. and their medicinal value. International Journal of Applied Biological Pharmaceutical Technology 3: 15-22.

11. Ezekiel T, Solomon L, Oforibika GA, Daminabo V (2016) Nutritional, Sensory and Bacteriological Quality of Two Varieties of Locally Prepared Zobo (Hibiscus sabdariffa) Drink. World Rural Observations, 8(3): 99104.

12. AOAC (Association of Official Analytical Chemists) (1990) Official Methods of Analytical Chemists, Washington, USA.

13. AOAC (2000) Official Methods of Analysis. (17 ${ }^{\text {th }}$ Ed.), Gaithersburg. MD, AOAC International Method, USA, pp. 92303.

14. Gbadamosi JO, Moody, Lawal AM (2011) Phytochemical screening and proximate analysis of eight ehnobotanicals used as antimalarial remedies in Ibadan, Nigeria. J Applied Bioscience 44: 2967-2971.

15. Ukam NU (2008) The potential of some lesser known vegetable. Nigerian Journal of Nutritional Science 29: 299-305.
16. Onwordi CT, Ogungbade AM, Wosu AD (2009) The proximate and mineral composition of three leafy vegetables commonly consumed in Lagos, Nigeria. African Journal of Pure \& Applied Chemistry 3(6): 102-107.

17. Antia S, Akpan EJ, Okon PA, Umoren IU (2006) Nutritive and antinutritive evaluation of sweet Potatoes (Ipomea batata) leaves. Pakistan Journal of Nutritional 5(2): 166-168.

18. Onunogbu IC (2002) Lipids in human existence, $\left(1^{\text {st }}\right.$ edn). Ap Express Publishing Company: Nsukka Nigeria.

19. Babalola OS, Tugbobo AS, Daramola 00 (2010) Effect of Processing on the Vitamin C Content of Seven Nigerian fruits. Advance Journal of Food Science and Technology 2(6): 303-305.

20. Tsado AN, Lawa B, Santali ES, Shaba AM, Chirama DN, et al. (2015) Effect of Different Processing Methods on Nutritional Composition of Bitter Leaf (vernonia amygdalina). IOSR Journal of Pharmacy 5 (6): 8-14.

21. Ekpa O, Ebana R (1991) Chemical composition of antimicrobial of leaves of four Nigerian plants with flavoring principles. Tropical Journal of Applied Science 1: 30-34.

22. Hutchinson J, Dalziel JM (1973) Flora of West Tropical Africa. 2nd Edition. Crown Agents for overseas Government and administration 1, Part 2. Pp. 638.

23. Okafor JC (1983) Horticulturally promising indigenous wild plants species of the Nigerian Forest Zones. Acts Horticulture 123: 165-177.

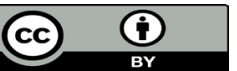

This work is licensed under Creative Commons Attribution 4.0 License

To Submit Your Article Click Here: Submit Article

DOI: 10.32474/CIACR.2019.07.000274

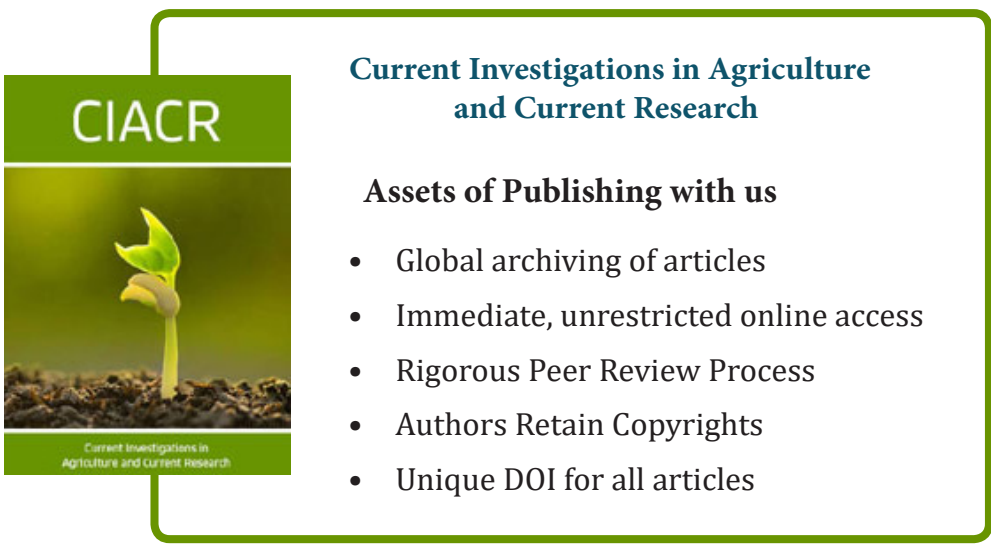

